\title{
Morphotectonic properties of the Lo River Fault near Tam Dao in North Vietnam
}

\author{
N. Q. Cuong ${ }^{1,3}$ and W. A. Zuchiewicz ${ }^{2,3}$ \\ ${ }^{1}$ Institute of Geological Sciences, Polish Academy of Sciences, Research Centre in Kraków, Kraków, Poland \\ ${ }^{2}$ Dept. of Geological Mapping and Tectonics, Institute of Geological Sciences, Jagiellonian University, Kraków, Poland \\ ${ }^{3}$ Galicia T. Group
}

Received: 7 May 2001 - Revised: 23 July 2001 - Accepted: 23 August 2001

\begin{abstract}
The Lo River fault near Tam Dao, North Vietnam, is a young, right-lateral, normal fault which has been active throughout the Quaternary. Rates of dextral slip range between 1 and $2 \mathrm{~mm} / \mathrm{yr}$ whereas rates of uplift can be estimated roughly at $0.1-1 \mathrm{~mm} / \mathrm{yr}$. The drainage deflection and arrangement of shutter ridges suggest $1.5-2.0 \mathrm{~km}$ of dextral offset during the past $1-2$ millions of years (m. y.), and the height of the youngest faceted spurs averages at $170 \mathrm{~m}$. Analysis of morphometric parametres of the mountain front at Tam Dao indicates that this segment shows properties typical for nearly rectilinear, young normal scarps that belong to class I or II of relative tectonic activity and that are capable of generating strong earthquakes in the future.
\end{abstract}

\section{Introduction}

The Red River Fault Zone (RRFZ) in Yunnan and North Vietnam, up to a dozen or so kilometres wide, is one of the main strike-slip fault zones in SE Asia that separates the South China and Indochina blocks (Fig. 1). The hitherto conducted studies suggest that it represents a large-scale shear zone formed in two phases: (1) during the left-lateral ductile shear active in $27-16 \mathrm{Ma}$ (culminating between $21-16 \mathrm{Ma}$, followed by an uplift and exhumation of crustal rocks from a depth of ca. $20-25 \mathrm{~km}$ ), and (2) as a right-lateral, primary brittle shear active in ca. 5.5 Ma (Allen et al., 1984; Tapponnier et al., 1990; Lacassin et al., 1993; Leloup et al., 1995; and references therein). However, recent fission-track studies indicate that the main period of ductile deformation in the RRFZ was finished by $25 \mathrm{Ma}$ (Anczkiewicz et al., 2000). The scale of sinistral offset has been estimated at $550-900 \mathrm{~km}$ (Leloup et al., 1995), and that of a young dextral one has been estimated at a few metres to $5.5 \mathrm{~km}$ and even $20-30 \mathrm{~km}$ (Allen et al., 1984; Trinh, 1995).

Correspondence to: W. A. Zuchiewicz

(witold@ing.uj.edu.pl)
In North Vietnam, the RRFZ is subdivided into three principal branches, up to $300 \mathrm{~km}$ long, orientated roughly NWSE and named, from the NE to SW, the Lo River, Chay River, and Red River faults (Figs. 2a and 3). These are primary dextral and dextral-normal faults that show the southeastwardincreasing component of normal slip (Trinh, 1995). Between the Lo and Chay River faults, recently growing anticlines, orientated WNW-ESE and W-E, have been found (Lacassin et al., 1994).

Neither in the Yunnan Province, nor in the North Vietnamese segment of the RRFZ, have earthquakes of $M>5.5$ been recorded (Fig. 3; Allen et al., 1984; Lap, 1989, 1991). This may point to either a long recurrence interval of strong earthquakes in this zone (Allen et al., 1984) and a presentday locking of the fault at a depth of 5-20 km (Cong and Feigl, 1999), or the predominance of fault creep mechanism in Pliocene-Quaternary times (Cuong et al., 1999). The hitherto conducted analyses of kinematic indicators found at exposures of Neogene conglomerates located in the SW limb of the Lo River fault (Cuong et al., 1999), indicating that small-scale tectonic structures originated during a few phases of brittle deformation, alternately extensional and compressional ones, the last one being compatible with dextral sense of movements along this zone. Moreover, the lack of fractured pebbles in Quaternary paraconglomerates in the RRFZ appears to suggest that fault creep must have been a dominating mechanism in the youngest stage of development of the area.

The aim of our study is to review all the available pieces of evidence in favour of young, right-lateral-normal slip in the SE portion of the RRFZ. Our research consists of field morphostructural and purely structural studies, as well as an analysis of the existing aerial photographs and topographic maps. A segment of the Lo River fault near Tam Dao has been selected as a test area (Fig. 2b), as it represents a prominent fault scarp that shows both strike-slip and strong normal components of motion. Moreover, this scarp has never been studied in detail. 


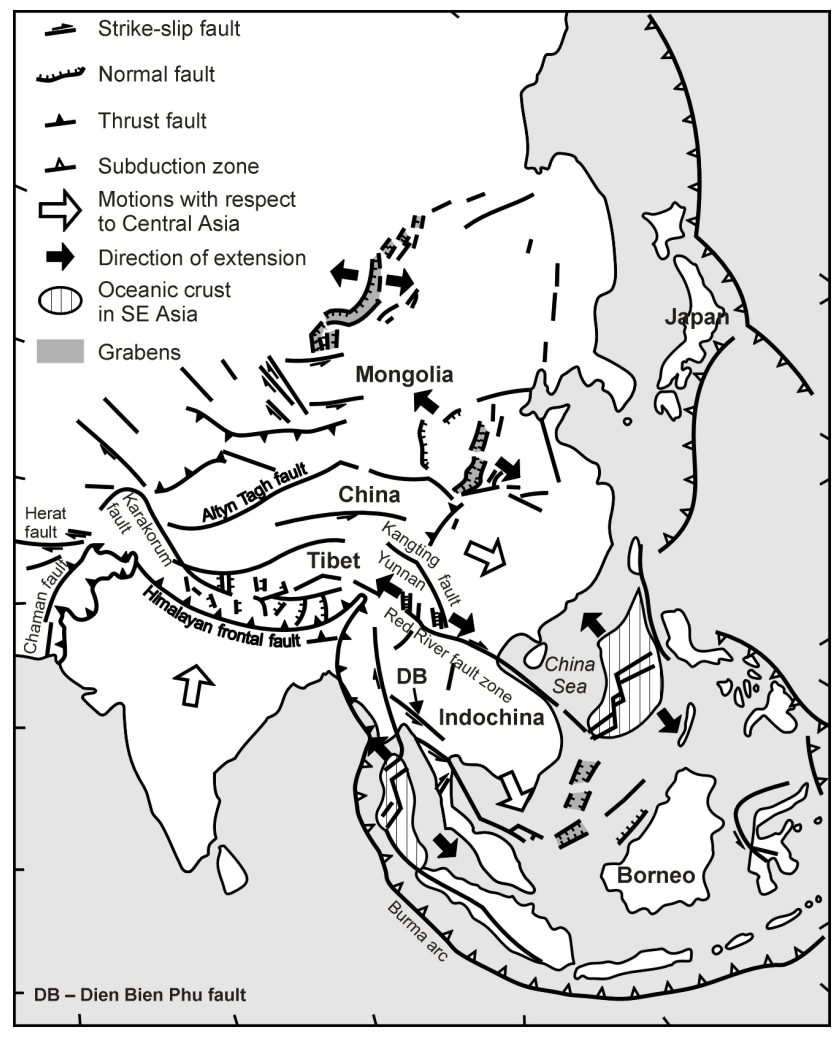

Fig. 1. Tectonic sketch of SE Asia (based on Tapponnier et al., 1982; Huchon et al., 1994). DB—Dien Bien Phu fault.

\section{Morphotectonic setting}

Morphotectonic features of the RRFZ in the Yunnan Province of China have been dealt with extensively by Allen et al. (1984) and recently by Weldon et al. (1994), whereas for the Vietnamese segment of this zone, only a few review and preliminary reports are available (i.e. Winter and Costaz, 1993; Lacassin et al., 1994; Trinh et al., 1993; Trinh, 1995; Cuong et al., 1999).

Indicators of the right-lateral slip, particularly well visible along some traces of the Chay River (north of Yen Bai) and Red River fault (Cam Duong, Trai Hut) segments are: drainage deflection (from $10-50 \mathrm{~m}$ to $2500 \mathrm{~m}$ ), beheaded streams, shutter ridges, en echelon orientated minor fault and fault-line scarps, displaced terraces and alluvial fans, rectilinear fault valleys, and long rectilinear fault scarps with reliefs not exceeding 30-50 m (Cuong et al., 1999). The amounts of right-lateral offset deduced from deflected drainage patterns and shown in Fig. 2a, are also portrayed in Fig. 4. Discrete figures obtained for $8-10 \mathrm{~km}$ to $20-25 \mathrm{~km}$ long fault segments range from 500 to $3000 \mathrm{~m}$; the cumulative offset amounting to $4-10 \mathrm{~km}$ and varying in individual RRFZ branches.

Morphotectonic indicators of predominantly normal slip in the SE segments of the Red River, Chay River and Lo River fault branches include: well developed triangular facets, the ubiquitous occurrence of overhanging wine-glass
Table 1. Valley floor width and valley height ratios calculated for valleys dissecting the Tam Dao scarp $1 \mathrm{~km}$ upstream of the mountain front (see Fig. 5 for location). Vfw, Eld - Esc, Erd - Esc in metres

\begin{tabular}{ccccc}
\hline site & $V f w$ & Eld-Esc & Erd-Esc & $V f$ \\
\hline 1 & 20 & 125 & 125 & 0.160 \\
2 & 25 & 220 & 90 & 0.161 \\
3 & 25 & 470 & 356 & 0.061 \\
4 & 75 & 460 & 520 & 0.153 \\
5 & 60 & 567 & 325 & 0.135 \\
6 & 50 & 348 & 260 & 0.164 \\
7 & 50 & 380 & 265 & 0.155 \\
8 & 50 & 347 & 350 & 0.143 \\
9 & 150 & 230 & 280 & 0.588 \\
10 & 100 & 105 & 196 & 0.664 \\
11 & 500 & 48 & 120 & 5.952 \\
\hline
\end{tabular}

Table 2. Basin elongation ratios and asymmetry factors of the Tam Dao scarp drainage basins (see Fig. 5 for location)

\begin{tabular}{ccccccc}
\hline basin & $A[\mathrm{sq} . \mathrm{km}]$ & $L[\mathrm{~km}]$ & $R e$ & $A R[\mathrm{sq} . \mathrm{km}]$ & $A F$ & $T$ \\
\hline $\mathrm{a}$ & 13.420 & 6.70 & 0.617 & 6.298 & 46.93 & 0.237 \\
$\mathrm{~b}$ & 10.240 & 5.50 & 0.657 & 6.000 & 58.59 & 0.212 \\
$\mathrm{c}$ & 9.378 & 5.80 & 0.596 & 4.170 & 44.46 & 0.224 \\
$\mathrm{~d}$ & 22.305 & 7.35 & 0.725 & 12.128 & 54.37 & 0.222 \\
$\mathrm{e}$ & 8.408 & 6.60 & 0.496 & 4.360 & 51.86 & 0.315 \\
$\mathrm{f}$ & 28.235 & 8.50 & 0.705 & 17.420 & 61.70 & 0.276 \\
\hline
\end{tabular}

$A$ - the basin area,

$L$ - the maximum basin length,

$A R$ - the area of the basin to the right (facing downstream) of the trunk stream,

$R e$ - the basin elongation ratio, $R e=(2 \sqrt{A}: \sqrt{\pi}) / L$;

$A F$ - the asymmetry factor; $A F=100(A R / A)$; the $A F$ is sensitive to tilting perpendicular to the main channel in a basin; $A F<50$ or $A F>50$ may suggest tilt;

$T$ - the transverse topographic symmetry factor; $T=D_{a} / D_{d}$, where $D_{a}$ is the distance from the midline of the drainage basin to midline of the active channel or meander belt, and $D_{d}$ is the distance from the basin midline to the basin divide; for perfectly symmetric basins $T=0$; as asymmetry increases, $T$ increases and approaches a value of 1.0 .

(hour-glass) valleys, and rectilinear fault scarps at the foot of mountain fronts, frequently accompanied by associated halfgrabens and minor horsts (Cuong et al., 1999). The most spectacular example of such features is provided by a fragment of the Lo River fault near Tam Dao.

\section{Morphotectonic indices}

Analysis of some morphometric parametres indicates that the Tam Dao scarp, although developed in a subtropical monsoon climate, shows properties typical for nearly rectilinear, 


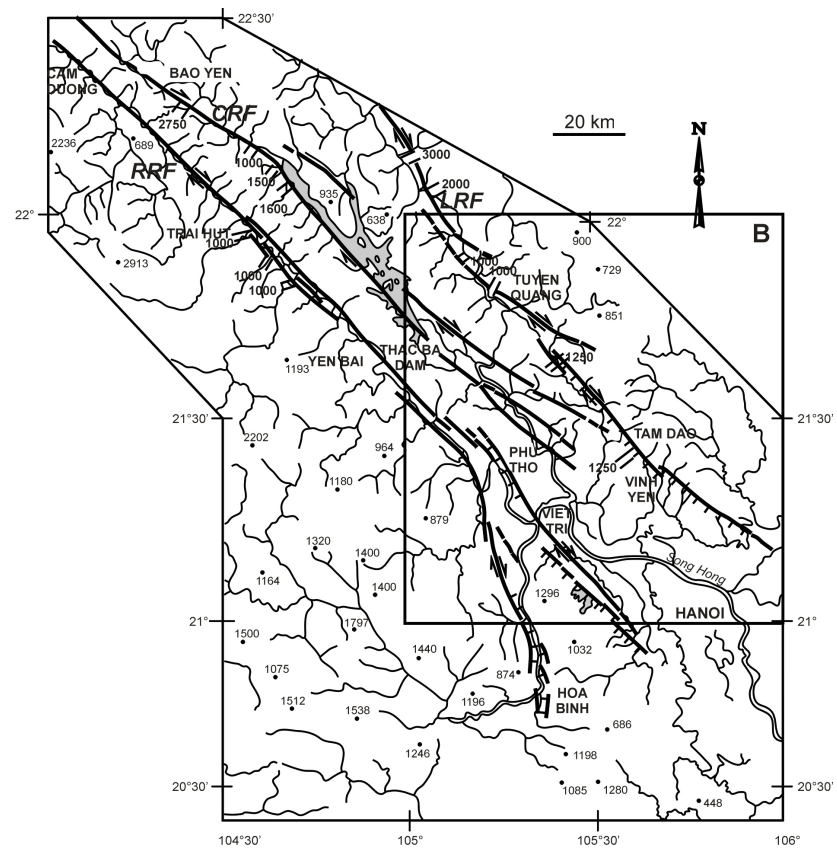

Fig. 2a. Young faults in the Vietnamese segment of the RRFZ (based on Trinh, 1995; modified). Sense of strike-slip motion is arrowed, barbed lines denote normal faults, bold numbers on the fault traces indicate recent offset (in metres) estimated from drainage deflection; the other numbers show elevation in metres above sea level (a.s.1.) RRFZ fault branches: RRF-Red River fault, CRF-Chay River fault, LRF-Lo River fault.

young normal fault scarps, described from the desert areas of Nevada and California (Bull, 1977, 1978).

The mountain front sinuosity index (Smf), (Bull, 1977, 1978 ) is calculated as a ratio of the length of the mountain front measured along the foot of the mountain at the pronounced break of the slope $(L m f)$ to the straight line length of the mountain front $(L s)$ :

$S m f=L m f / L s$.

Mountain fronts associated with active uplift are relatively straight, with low values of $(S m f)$, which in arid areas of the Basin and Range Province, range between 1.0 and 1.6. For slightly active and inactive regions, the $\operatorname{Sm} f$ values tend to be between 1.4-3.0 and 1.8 to $>5$, respectively. Values calculated for the Tam Dao mountain front (Fig. 9) vary from 1.04 to 1.16 . These figures, even corrected for resistance contrast of bedrock rocks on either side of the Lo River fault, point to a relatively high activity of recent uplift.

The same conclusion comes from an analysis of other morphometric indices, including the valley floor width and valley height ratios (Bull, 1977, 1978; Bull and McFadden, 1977), showing abnormally low values for valleys that truncate the Tam Dao mountain front. This parameter is calculated as:

$V f=2 V f w /[(E l d-E s c)+(E r d-E s c)]$,

where $V f w$ is the width of the valley floor, Eld and Erd are the elevations of the left and right valley divides, respectively, and $E s c$ is the elevation of the valley floor. This index

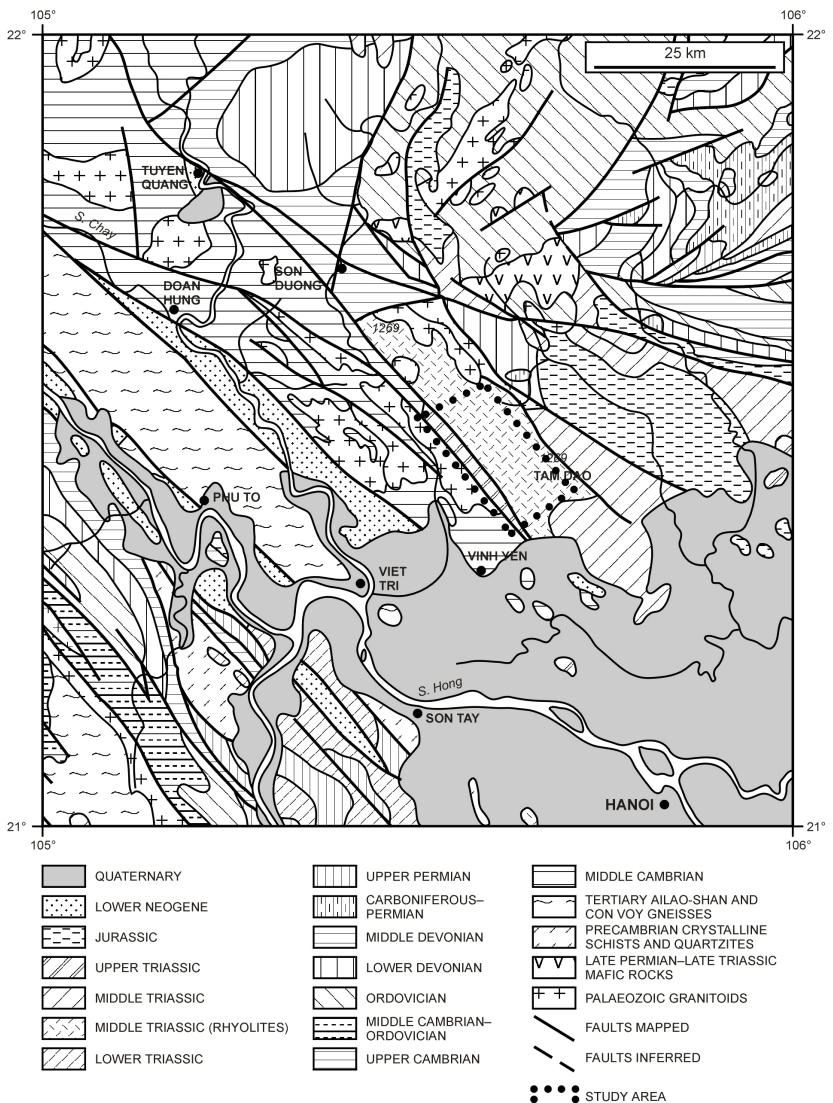

Fig. 2b. Simplified geological map of the south eastern portion of the RRFZ close to Tam Dao (based on Tri et al., 1973, simplified). Numbers indicate elevation in metres above sea level (a.s.l.).

differentiates between broad-floored valleys, with relatively high values of $V f$, and $\mathrm{V}$-shaped canyons with relatively low values. Low values of $V f$ reflect deep valleys of actively incising streams, commonly associated with uplift (Keller and Pinter, 1996). The figures quoted by Bull and McFadden (1977) for the Basin and Range Province range between 0.05-47, averaging at 1.3-11.0. Valleys dissecting the Tam Dao mountain front display $V f$ values (calculated for valley segments located $1 \mathrm{~km}$ upstream of the mountain front) ranging between 0.061-5.952 (av. 0.758). Excluding the broadest valley at the SE margin of the studied segment $(* 11$ in Fig. 5; Table 1), the obtained values are much smaller, averaging at $0.238(0.061-0.664)$.

\section{Tam Dao scarp: a normal right-lateral segment of the Lo River Fault}

The Lo River fault is divided into three en echelon arranged segments (Fig. 2a), striking roughly NW and showing variable amounts of right-lateral offset in the drainage pattern. These are, from the NW direction, the Thac Dal - Nac Yem, Lang The - Tuyen Quang, and Tam Dao segments (Winter and Costaz, 1993). 


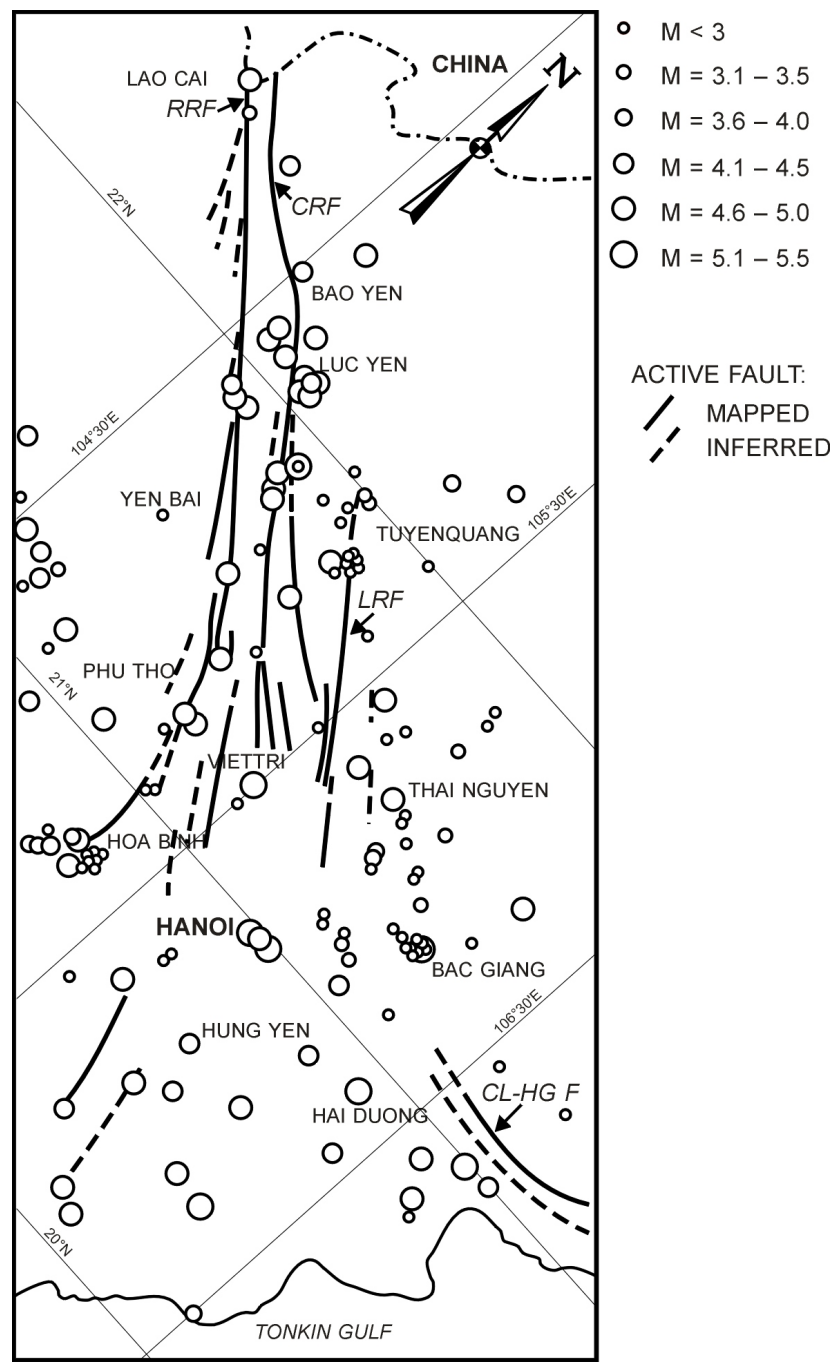

Fig. 3. Pattern of historic seismicity in the RRFZ in northern Vietnam. RRF-Red River fault, CRF-Chay River fault, LRF-Lo River fault, CL-HG F-Chi Linh - Hon Gai fault.

The area chosen for a detailed study includes the Tam Dao mountain front, rising $1200-1300 \mathrm{~m}$ a.s.l. and built up of middle Triassic (Anisian) rhyolites and rhyolitic porphyrites. This massif is cut on the SW by a narrow graben filled with upper Triassic strata of the Van Lang suite, composed of shales, sandstones, conglomerates and some limestone intercalations, unconformably covered by a thin veneer of fluvial and proluvial Quaternary sediments (Fig. 2b). Farther southwestwards, a horst built up of middle Cambrian phyllites, quartzites and oolithic limestones of the Hagiang Formation occurs (Tri, 1973; Tri et al., 1979).

The orientation of the Tam Dao fault scarp is from $\mathrm{N} 42^{\circ} \mathrm{W}$ to $\mathrm{N} 29^{\circ} \mathrm{W}$, with its length near Tam Dao reaching some $20 \mathrm{~km}$ (Fig. 5). The scarp rises from nearly 150-200 $\mathrm{m}$ to $1200 \mathrm{~m}$ above the alluvial plain (from SE to NW) and its relief decreasing markedly towards the SE, as shown by a sequence of topographic cross-profiles drawn every $1 \mathrm{~km}$ through the Tam Dao mountain front (Fig. 6). The ridge crest

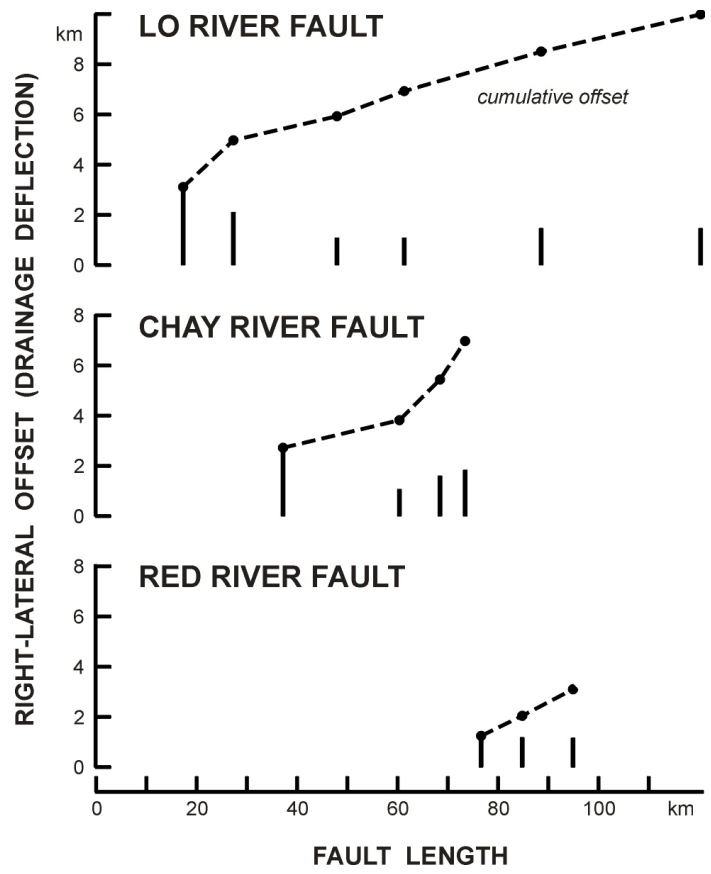

Fig. 4. Amount of recent dextral offset along the main branches of the RRFZ, calculated for the segment shown in Fig. 2a.

long profile is not uniform, dropping by some $250-300 \mathrm{~m}$, in a zigzag-like pattern, in the highest elevated part (Fig. 7), probably due to bedrock-controlled erosion. In the middle part of the mountain front, a few breaks of slope are clearly marked at elevations diminishing southeastwards, from 850 to $90 \mathrm{~m}$. These breaks coincide at places with secondary faults parallel to the Lo River fault which cuts the mountain front in the south-west (Fig. 8). Along the latter, a spectacular basal scarp of variable height (averaging at $170 \mathrm{~m}$ ) is found. The scarp attains the highest relief in the medial sector of the studied fault segment (Figs. 7, 8a and 8d).

The Tam Dao mountain front is deeply dissected by Vshaped valleys and gullies of relief exceeding at places $550 \mathrm{~m}$. These valleys form a dendritic pattern and belong to several long and narrow, usually symmetric, drainage basins. The asymmetry factor AF (Hare and Gardner, 1985) does not differ much from 50, showing that the basins have not been tilted, and the transverse topographic symmetry factor values $T$ (Cox, 1994) range between 0.21 and 0.32 , i.e. typically for nearly symmetric basins (Table 2)

This segment of the Lo River fault also displays a strikeslip component of motion. Judging from the presence of shutter ridges at the foot of the scarp and drainage deflection (Figs. 5 and 8f), the young, right-lateral component of slip does not exceed 1500-2000 m. The shutter ridges rise 20$35 \mathrm{~m}$ above the surrounding alluvial plain and their lengths rarely exceed $1 \mathrm{~km}$. Drainage deflection is clearly marked at the foot of the main fault scarp, as well as along the subsidiary faults that parallel the Lo River fault in the south-west (Fig. 5).

The basin elongation ratio (Bull and McFadden, 1977) is 


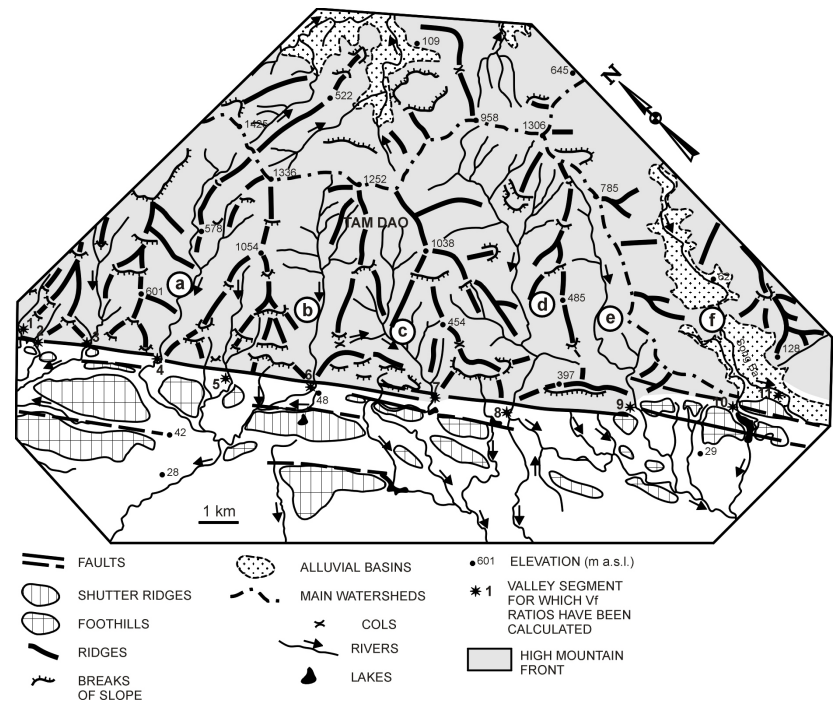

Fig. 5. Simplified sketch of the Tam Dao mountain front. Letters (a) through (f) indicate catchment areas for which physiographic parametres have been calculated.

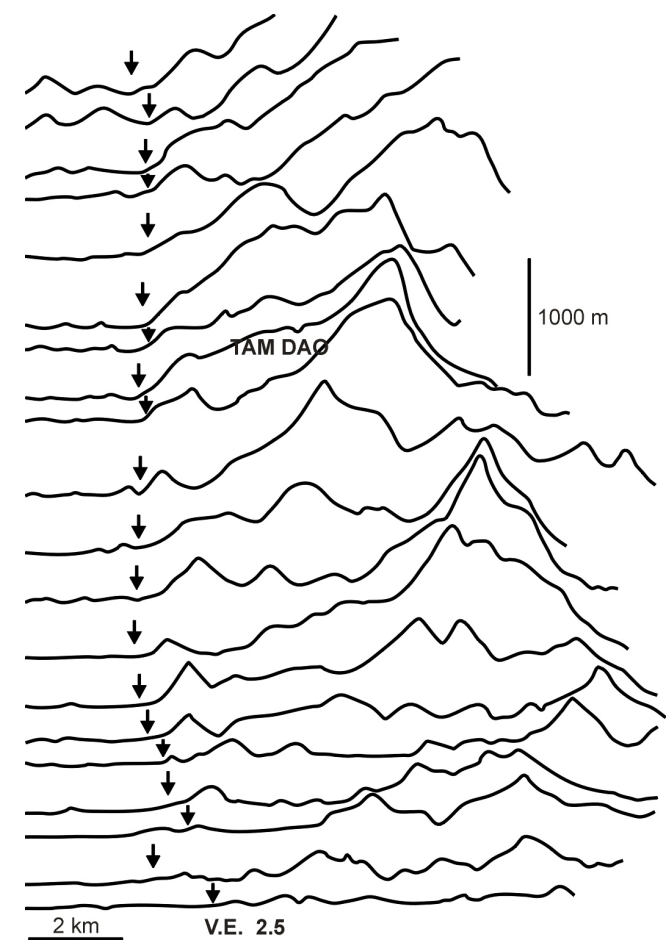

Fig. 6. Topographic profiles orientated $\mathrm{N} 55^{\circ} \mathrm{E}$, drawn every $1 \mathrm{~km}$ across the Tam Dao mountain front in a segment shown in Fig. 5. Position of the Lo River fault is arrowed.

one of the proxy indicators of recent tectonic activity. This parameter $(R e)$ is calculated as a ratio of the drainage basin area $(A)$ to the maximum basin length $(L)$, i.e. the distance between the two most distant points in the drainage basin:

$R e=(2 \sqrt{A}: \sqrt{\pi}) / L$.

Drainage basins in arid and semiarid climates tend to show

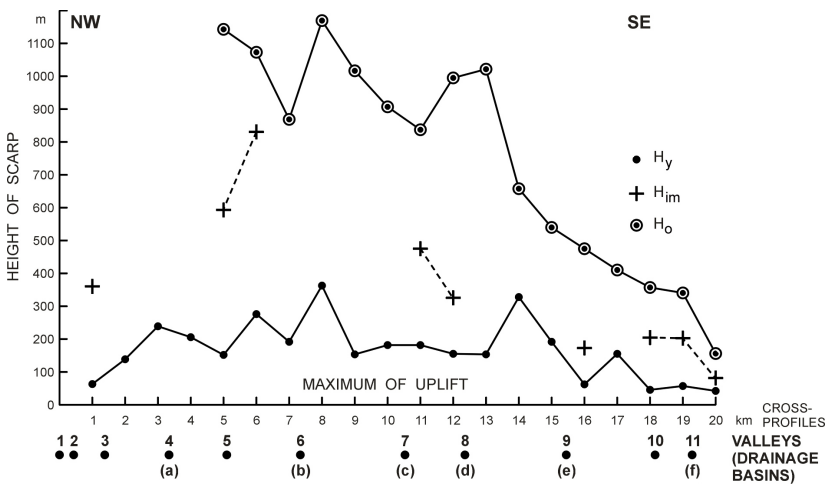

Fig. 7. Plot showing heights of young scarps $\left(H_{y}\right)$, intermediate breaks of slope $\left(H_{i m}\right)$ and the oldest ridge crests $\left(H_{O}\right)$ along the Tam Dao mountain front.

$R e$ values ranging from $<0.50$, through $0.50-0.75$ to $>0.75$ for tectonically active, slightly active and inactive settings, respectively. The $R e$ values have been calculated for six small drainage basins located on the SW slope of the Tam Dao mountain front (Fig. 5a to 5f). These figures range from 0.496 to 0.725 , pointing to a slightly active uplift of the footwall of the Lo River fault in this segment (Table 2).

All these morphometric data (Figs. 9 and 10) enable us to consider the Tam Dao fault scarp as one that belongs to the class I or II of relative tectonic activity (Bull, 1978), and is capable of producing strong earthquakes in the future. Boundary values of these classes have been obtained in arid and semiarid areas of recently active extensional settings of the Basin and Range Province. It could be expected that analogous figures calculated for an area of an entirely different subtropical monsoon climate of SE Asia should be different. On the contrary, it turned out that the freshness of tectonic landforms indicates relatively high rates of displacement results in morphometric properties which are very similar to those of the Basin and Range Province. These rates, confirmed by the results of geodetic measurements, will be discussed at large in the following section.

\section{Discussion}

Estimation of the rate of uplift and strike-slip motion along the Tam Dao segment of the Lo River fault is difficult at this stage of study, due to poor age control of the displaced Neogene and Quaternary strata. Fast uplift of the Tam Dao region has already been suggested by Lacassin et al. (1994) and Trinh (1995), without quoting any rates. Taking into account the heights of the lowest fault scarp and the highest mountain crest (Figs. 6 and 7), however, one can hypothesize about their possible age by applying different rates of uplift suggested by recent geodetic surveys (Table 3 ). Repeated precise levelling in the years between 1963-1985 (To and Yem, 1991) indicates that present-day vertical crustal motions in the SE segment of the RRFZ range from $+1 \mathrm{~mm} / \mathrm{yr}$ close to Viet Tri to $-2 \mathrm{~mm} / \mathrm{yr}$ SE of Hanoi. On the other hand, a 


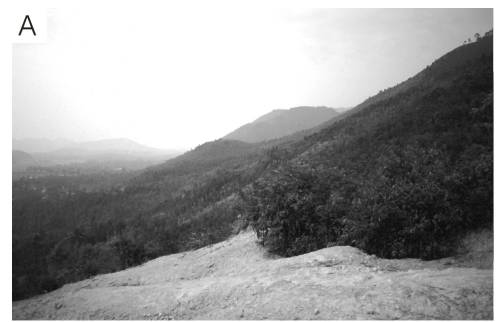

D
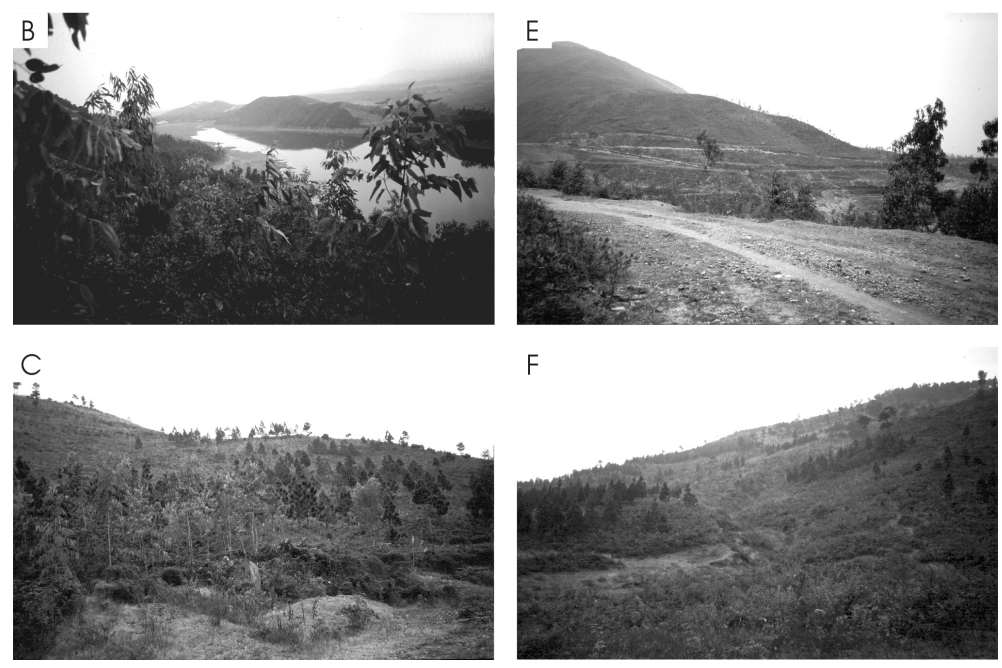

Fig. 8. Details of the Tam Dao mountain front: (A) looking NW along a scarp of a subsidiary fault, parallel to the Lo River fault, (B) looking SE upon a small graben south of Tam Dao village, (C) SE portion of the mountain front, looking NE upon two en echelon minor fault-line scarps, (D) Tam Dao fault scarp SE of $* 9$ in Fig. 5, (E) two subparallel fault-line scarps in the SE portion of the studied segment, $(\mathrm{F})$ looking NW of *8 in Fig. 5 upon a shutter ridge (20-30 $\mathrm{m}$ high) that blocks the outlet of a small valley dissecting the fault scarp.

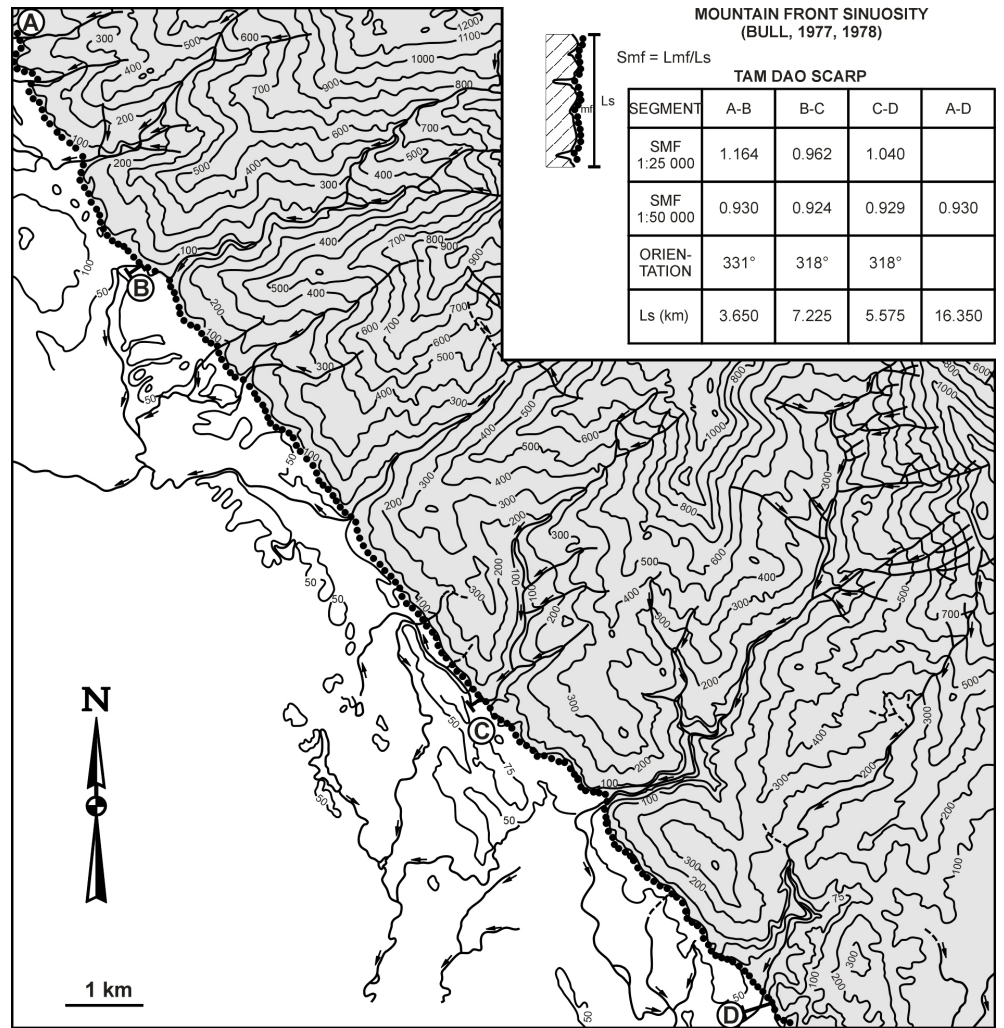

Fig. 9. Topographic sketch of the Tam Dao mountain front (segment comprised between $* 1$ and $* 9$ in Fig. 5; (A) $* 1$, (B) *4, (C) *7, (D) *9) showing very low values of the mountain front sinuosity, calculated on both $1: 25000$ and $1: 50000$ topographic maps. recent GPS study reveals no significant motions across the fault zone that would exceed $0.3 \mu \mathrm{rad} / \mathrm{yr}$ (Cong and Feigl, 1999). Therefore, rates ranging from 0.1 to $1 \mathrm{~mm} / \mathrm{yr}$ appear to be plausible estimates (Table 3). A word of caution should be added, since we have no substantial reason to assume that such rates have been constant through time. By taking the 
Table 3. Estimation of the age of uplift of the Tam Dao mountain block $\left(H_{O}\right)$ and the youngest fault scarp $\left(H_{y}\right)$ at its base, depending on possible uplift rates. Bold numbers indicate average values

\begin{tabular}{cccc}
\hline area rate & $1 \mathrm{~mm} / \mathrm{yr}$ & $0.5 \mathrm{~mm} / \mathrm{yr}$ & $0.1 \mathrm{~mm} / \mathrm{yr}$ \\
\hline$H_{O}$ & $0.15-1.18 \mathrm{Ma}$ & $0.30-2.36 \mathrm{Ma}$ & $1.50-11.80 \mathrm{Ma}$ \\
& $\mathbf{7 6 0 ~ k a}$ & $\mathbf{1 . 5 0} \mathbf{M a}$ & $\mathbf{7 . 6 0} \mathbf{M a}$ \\
& & & \\
$H_{y}$ & $50-360 \mathrm{ka}$ & $100-730 \mathrm{ka}$ & $0.50-3.60 \mathrm{Ma}$ \\
& $\mathbf{1 7 0 ~ k a}$ & $\mathbf{3 4 0} \mathbf{~ k a}$ & $\mathbf{1 . 7 0} \mathbf{M a}$ \\
\hline
\end{tabular}

minimum rates $(0.1 \mathrm{~mm} / \mathrm{yr})$, we obtain the age of uplift of the highest crest of the Tam Dao massif as 7.6 Ma, and the age of uplift of the lowest fault scarp at around 1.7 Ma. The first figure is compatible with the age of termination of the leftlateral motion along the RRFZ in the Hanoi graben, dated by Phach and Que (1999) to 8-6 Ma. The maximum rates, in turn, make it possible to estimate the age of the highest crest and the fault scarp at $760 \mathrm{ka}$ and $170 \mathrm{ka}$, respectively, i.e. coinciding with the Brunhes/Matuyama boundary and the penultimate glacial stage. A future solution to this problem lies both in a fission-track study and the precise dating of the Quaternary strata displaced by the Lo River fault.

The amount of right-lateral slip deduced from the drainage deflection of streams dissecting the Lo River fault at the foot of the Tam Dao scarp ranges from 1500 to $2000 \mathrm{~m}$. The exact age of this displacement is difficult to assess due to the lack of dating of Quaternary fluvial sediments. The nearest area where the Holocene right-lateral displacement of $30 \mathrm{~m}$ has been documented is the Thac Ba dam on the Chay River fault (Pho et al., 1999; also Fig. 2a). Taking this figure as a proxy for young dextral motions in the SE segment of the RRFZ, we obtain a $3 \mathrm{~mm} / \mathrm{yr}$ rate of recent strike-slip movements and a 500-670 ka age of displacement on the Tam Dao scarp. GPS surveys indicate the rates of slip ranging between 1 and $5 \mathrm{~mm} / \mathrm{yr}$ (Cong and Feigl, 1999) in this region, whereas displaced geomorphic markers in the Yunnan segment of the RRFZ suggest fault-slip rates of 2 to $5 \mathrm{~mm} / \mathrm{yr}$ (Allen et al., 1984), with a most likely value being $2 \mathrm{~mm} / \mathrm{yr}$ (Weldon et al., 1994). The Chay River fault is the fastest slipping strike-slip fault of the RRFZ; hence, a more plausible estimate for the Quaternary rates of the Lo River fault near Tam Dao would be $1-2 \mathrm{~mm} / \mathrm{yr}$. In such a case, the age of displacement in this fault segment could be put into a 1-2 Ma interval. On the other hand, Winter and Costaz (1993) concluded that about a 5-7 km right-lateral ridge displacement along the whole Tam Dao segment of the Lo River fault exists, which would imply the onset of displacement at 3.5 or even $7 \mathrm{Ma}$. These figures should, however, be treated with utmost caution until we obtain reliable age estimations.

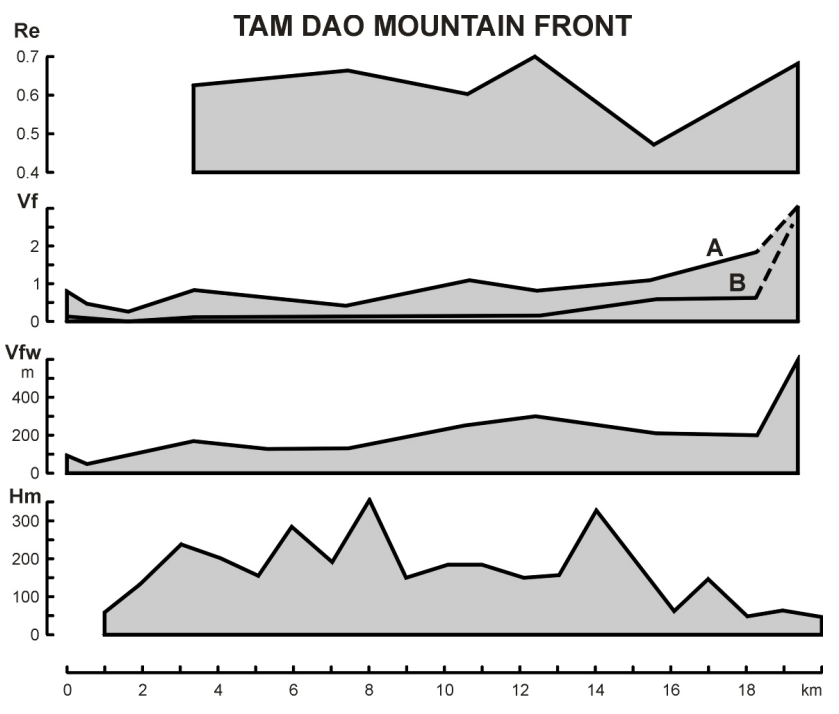

Fig. 10. Diagrams summarising physiographic parametres of the Tam Dao mountain front comprised between $* 1$ and $* 11$ in Fig. 5 . Abbreviations: $R e$ - basin elongation ratio, $V f$ - valley floor width-valley height ratio (calculated (A) at the mountain front, (B) $1 \mathrm{~km}$ upstream), $\mathrm{Vfw}$ - valley floor width, $\mathrm{Hm}$ - height of the youngest fault-line scarp.

\section{Conclusions}

The Tam Dao segment of the Lo River fault is an oblique active fault showing 1-2 mm/yr rates of dextral slip and at least a $0.1 \mathrm{~mm} / \mathrm{yr}$ rate of uplift during the past $1-2 \mathrm{Ma}$ and $1.7 \mathrm{Ma}$, respectively. Analysis of some morphometric parametres indicates that the Tam Dao scarp, although developed in a subtropical monsoon climate, has properties typical for nearly rectilinear, young normal fault scarps, described from the desert areas of Nevada and California. For instance, the mountain front sinuosity index varies from 1.04 to 1.16 . These figures, although corrected for resistance contrast of bedrock rocks on either side of the fault, point to a relatively high activity of recent uplift. The same conclusion comes from an analysis of other morphometric indices, including the valley floor width/valley height ratios or basin elongation ratios, showing abnormally low values for valleys that truncate the studied mountain front. These data enable us to consider the Tam Dao fault scarp as one that belongs to the class I or II of relative tectonic activity, and is capable of producing strong earthquakes in the future.

Acknowledgements. This research has been supported in part by the State Committee for Scientific Research of Poland (KBN) through grant no. 6 PO4E 02618 (to W. A. Zuchiewicz), and Galicia T. Group. We are greatly indebted to Prof. Dr. Nguyen Trong Yem from National Center of Science and Technology in Hanoi for encouragement and logistic support, and Assoc. Prof. Dr. T. D. To for the most recent results of GPS campaigns in Vietnam. We would also like to acknowledge two anonymous Reviewers for helpful comments and suggestions. 


\section{References}

Allen, C. R., Gillespie, A. R., Han, Y., Sieh, K. E., Zhun, B., and Zhu, Ch. N.: Red River and associated faults, Yunnan Province, China: Quaternary geology, slip rates, and seismic hazard, Geol. Soc. Am. Bull., 95, 686-700, 1984.

Anczkiewicz, R., Viola, G., Cuong, N. Q., and Chi, C. T.: Structural and fission track study of the Red Rive shear zone in N-Vietnam, In: R. Cocks (Ed.), Abstracts, Geoscience 2000. Univ. of Manchester, 17-20 April 2000, Geol. Soc. London, Manchester, 123, 2000.

Bull, W. B.: Tectonic geomorphology of the Mojave Desert. U.S. Geol. Surv. Contract Rep. 14-08-001-G-394, Office of Earthquakes, Volcanoes and Engineering, Menlo Park, Calif., pp. 188, 1977.

Bull, W. B.: Geomorphic tectonic activity classes of the south front of the San Gabriel Mountains, California, U.S. Geol. Surv. Contract Rep. 14-08-001-G-394, Office of Earthquakes, Volcanoes and Engineering, Menlo Park, Calif., pp. 59, 1978.

Bull, W. B. and McFadden, L. D.: Tectonic geomorphology north and south of the Garlock fault, California, In: Geomorphology in Arid Regions, Proc. 8th Ann. Geomorph. Symp., (Ed) Doehring, D. O., State Univ. of New York at Binghamton, 115-138, 1977.

Cong, D. Ch. and Feigl, K. L.: Geodetic measurement of horizontal strain across the Red River fault near Thac Ba, Vietnam, 19631994, J. Geod., 73, 298-310, 1999.

Cox, R. T.: Analysis of drainage-basin symmetry as a rapid technique to identify areas of possible Quaternary tilt-block tectonics: an example from the Mississippi embayment, Geol. Soc. Am. Bull., 106, 571-581, 1994.

Cuong, N. Q., Zuchiewicz, W., and Tokarski, A. K.: Morphotectonic evidence for right-lateral normal slip in the Red River Fault Zone: insights from the study on Tam Dao fault scarp (Viet Nam), J. Geol., Ser. B, 13-14, 57-59, Hanoi, 1999.

Hare, P. W. and Gardner, T. W.: Geomorphic indicators of vertical neotectonism along converging plate margins, Nicoya Peninsula, Costa Rica, In: Tectonic Geomorphology: Proceedings of the 15th Annual Binghamton Geomorphology Symposium, (Eds) Morisawa, M. and Hack, J. T., September 1984, Allen and Unwin, Boston, 90-104, 1985.

Huchon, P., Le Pichon, X., and Rangin, C.: Indochina Peninsula and the collision of India and Eurasia, Geology, 22, 27-30, 1994.

Keller, E. A. and Pinter N.: Active Tectonics: Earthquakes, Uplift, and Landscape, Prentice Hall, Upper Saddle River, New Jersey, pp. 338, 1996.

Lacassin, R., Leloup, P. H., and Tapponnier, P.: Bounds on strain in large Tertiary shear zones of SE Asia from boudinage restoration, J. Struct. Geol., 15, 677-692, 1993.

Lacassin, R., Tapponnier, P., Leloup, P. H., Trinh, P. T., and Yem, N. T.: Morphotectonic evidence for active movements along the Red River fault zone, Actes du Colloque, Colloq. Int. Sur la sismotectonique et le risque sismique en Asie du Sud Est, 27 Janv.-4 Fevr. 1994, Hanoi, 66-71, 1994.

Lap, N. K.: Seismicity of the territory of Vietnam, Acta Geophys. Polon., 37, 248-261, 1989.

Lap, N. K.: A note on earthquakes in the Hanoi district in Vietnam, Acta Geophys. Polon., 39, 223-231, 1991.

Leloup, P. H., Lacassin, R., Tapponnier, P., Schärer, U., Zhong, D., Liu, X., Zhang, L., Ji, Sh., and Trinh, P. T.: The Ailao Shan - Red River shear zone (Yunnan, China), Tertiary transform boundary of Indochina, Tectonophysics, 251, 3-84, 1995.

Phach, Ph. V. and Que, B. C.: Late Cenozoic tectonic activity in North Vietnam, J. Geol., Ser., B, 13-14, 33-41, Hanoi, 1999.

Pho, N. V., Nga, H. T., and Tra, D. T.: Study on the stability of Thac Ba hydropower dam by using nuclear track detector method, J. Geol., Ser. B, 13/14, 270-271, Hanoi, 1999.

Tapponnier, P., Lacassin, R., Leloup, P. H., Schärer, U., Zhong, D., Haiwei, W., Liu, X., Ji, Sh., Zhang, L., and Zhong, J.: The Ailao Shan/Red River metamorphic belt: Tertiary left-lateral shear between Indochina and South China, Nature 343, 431-437, 1990.

Tapponnier, P., Peltzer, G., LeDain, A. Y., Armijo, R., and Cobbold, P.: Propagating extrusion tectonics in Asia: new insights from simple experiments with plasticine, Geology, 10, 611-616, 1982.

To, T. D. and Yem, N. T.: Vertical movements of the territory of Vietnam (North part) by repeated precise levelling, Geology, 202-203, 20-27, Hanoi (in Vietnamese with English abstract), 1991.

Tri, T. V. (Ed.), Geological map of Viet Nam 1: 1000 000. The General Geological Department of the Democratic Republic of Vietnam, Hanoi, 1973.

Tri, T. V. et al.: Geology of Vietnam (north part), Res. Inst. Geol. Miner. Res., Hanoi, pp. 80, 1979.

Trinh, Ph. T.: Influence des failles actives sur les réservoirs de Hoabinh et de la rivière Chay (nord du Viet Nam), In: Télédétection des ressources en eau. Actes des journées scientifiques de Tunis 1993, (Eds) Dubois, J.-M., Boussema, M. R., Boivin, F., and Lafrance, P., Universités Francophones, Actualité Scientifique, AUPELF, Presses de l'Université du Québec, Sainte-Foy, Montréal, 31-42, 1995.

Trinh, Ph. T., Lacassin, R., Tapponnier, P., Leloup, P. H., and Yem, N. T.: Evidence for active strike-slip movements in Northwestern Vietnam, Terra Abstracts, Abstract Suppl. No. 1 to Terra Nova, 5, 265, 1993.

Weldon, R., Sieh, K., Zhu, Ch. N., Han, Y., Yang, J. W., and Robinson, S.: Slip rate and recurrence interval of earthquakes on the Hong He (Red River) fault, Yunnan, PRC, Proc. IWSSH-SEA, 27 Jan.-4. Feb. 1994, Hanoi, 244-248, 1994.

Winter, T. and Costaz, J.: Hoa Binh area. Geological mapping, UNDP Program VIE/92/035, Coyne et Bellier, Paris, 51 ms. pp. (unpublished report), 1993. 